\title{
History Online Challenges and Curriculum Engineering during the COVID-19 Pandemic
}

\section{Kalpana Hiralal ORCID iD: https://orcid.org/0000-0002- $\underline{1733-4643}$}

\section{Vanessa Noble ORCID iD: https://orcid.org/0000-0001- $\underline{5112-0705}$}

\section{Abstract}

This article focuses on teaching and learning strategies and curriculum shifts in light of our large first-year History module 'The Making of the Modern World' (HIST 104) at the University of KwaZulu-Natal during the first few months of the 2020 Covid-19 pandemic. This course was designed to encourage our students to consider the issue of globalisation, pushing them to move beyond the nation-state focus of much of school taught history. The importance of the connection between different peoples and regions is a central focus of this course and this article. Here we reflect on re-thinking our strategies for our first-year course in our present - globalised and connected but still vastly unequal - teaching and learning world. While we have used Moodle for years as an aid to accompany our face-to-face teaching of our first-year students, during the pandemic we were confronted with developing a fully online teaching approach, but with a myriad of challenges and inequalities due to students' poor access to technology and digital services. This article, therefore, highlights the approach we took and challenges we faced teaching our HIST 104 module amid this pandemic and how it pushed two historians to reevaluate and reconceptualise their teaching material.

Keywords: History, online teaching, curriculum, challenges, COVID-19, University of KwaZulu-Natal, South Africa 
South Africans and people around the world are presently experiencing one of the most severe public health crises - the Covid-19 pandemic $^{1}$. In December 2019, the World Health Organisation (WHO) received reports of a virus affecting people in the large city of Wuhan in China. This virus, which was named Covid-19, was a coronavirus that caused severe respiratory illness in humans. Globally, the pandemic has spread at an alarming rate. It has spread to most countries in the world, with the United States, India, Brazil and Russia amongst the countries most severely affected thus far. As of 7 September 2020, there were well over 27 million cases of Covid-19 reported, with over 893,000 deaths ('Coronavirus Cases', Worldometer, 7 September 2020). During the last few months, governments globally have issued stay-at-home orders or lockdowns to try to slow its spread, and economies around the world have been severely affected. Indeed, during the present lockdown period in South Africa, which is still underway, both schools and universities were closed in mid-March. Now in early September 2020, while finishing this article, although most schools have reopened, most university students have still not returned to their face-to-face contact studies due to the difficulty of maintaining social distancing regulations in large lecture theatre environments. These institutional closures have disrupted school and tertiary education systems substantially. They also pose a severe threat to the remainder of the academic year from a curriculum perspective.

This article reflects critically on the disruptions that Covid-19 brought to our higher education teaching and learning experiences, and how we tried to respond to these challenges. As historians, our task is to reflect on past issues critically. Hence, it seems surreal not only to reflect but also to document the current pandemic, knowing that this event will be historicised in the future. To anchor this paper, we focused on our experiences of teaching one of our History courses at the University of KwaZulu-Natal (UKZN) entitled 'The Making of the Modern World' during the pandemic. Although we teach other History modules at UKZN, we decided to focus on this course as it is here that we have faced the most challenges in terms of providing high-quality teaching and learning to a large class of first-year students at this difficult time. Interestingly, this course also touches on a subject matter that directly speaks to issues we are all currently

${ }^{1}$ This chapter was completed in September 2020 in the midst of the first wave of the COVID-19 pandemic in South Africa. 
living through - globalisation - including the impact of diseases on world history.

Drawing on our personal experiences in this article, as well as online sources, including UKZN email communications from our managers and students, UKZN online survey documents, and news media sources, we consider how present-day challenges have pushed us to reevaluate and reconceptualise our teaching material. We reflect on how we have had to rethink our strategies for our first-year History course in our present globalised and connected but still vastly unequal - teaching and learning world. For years, our teaching methodology consisted of the online teaching aid - Moodle ${ }^{2}$ - together with traditional face-to-face lectures and tutorials. However, in recent months Covid-19 has compelled us to develop a teaching approach for our course that is fully online, but with a myriad of challenges and inequalities due to our students' lack of access to technology and digital services.

\section{History 104: The Making of the Modern World}

The authors of this article have both been teaching History 104, in the Historical Studies programme at UKZN for over ten years. It has been taught for a much longer period at UKZN since we inherited an earlier version of this course from our History colleague Julie Parle ${ }^{3}$. Although various aspects of the course have been revised and adapted over the years by different lecturers, it has been and remains one of UKZN's seminal History courses. Indeed, it is our programme's foundational first-year survey course, which all students majoring in History are required to complete, and many others take as an elective for their other degrees.

This course seeks to teach history from a global perspective. It has been designed to encourage students to think broadly, that is, beyond individual countries or states, which drives the focus of most school-taught history (Moore 1997: 943, 949). Instead, 'The Making of the Modern World'

\footnotetext{
${ }^{2}$ Moodle is an open source online learning platform.

${ }^{3}$ Although lecture focus areas, readings and assessments have changed over the years, Associate Professor Julie Parle, who no longer works at UKZN, was instrumental in providing us with the overall conceptual framework for this course.
} 
examines several centuries of world history from circa 1000 AD to about the mid-1700s. Undeniably, the central issue guiding this course is the issue of globalisation, how 'different societies have gradually been brought closer together' and become more 'interconnected' or 'integrated' during this period, which greatly influenced their historical development (Ponting 2001: 3; Cooper 2001: 189, 196). Hence, we begin with an analysis of the years between 1000 and the late 1300s AD, a period that historian Janet AbuLughod has labelled the 'First World System' (Abu-Lughod 1989). This period that saw the growth of interregional cross-cultural interactions between Afro-Eurasian peoples who became more interconnected through long-distance trade, migration and conquest (Abu-Lughod 1989: 3, 8, 13; Tignor et al. 2008: 418, 421, 467 - 468). Significantly, these connections stimulated many exchanges, including belief systems, languages, intellectual ideas, new inventions, technologies and other goods, which spurred the development of different societies (Ponting 2001: 3, 7, 10 - 12). This was particularly the case for Europe, a peripheral region during the period of the 'First World System', which was profoundly influenced by the innovative ideas and technologies that spread to them from the more dynamic Islamic and Asian societies (Abu-Lughod 1989: 13; Ponting 2001: 1, 3-5, 9 - 10).

Europeans benefitted from the technologies that came to them from 'the East', which enabled them to embark on their fifteenth-century exploratory voyages into the Atlantic Ocean that led them to circumnavigate Africa and the accidental 'discovery' of the Americas in 1492. This latter act, set in motion the true connection of the world with the bringing together of the Western and Eastern Hemispheres for the first time after being separated for thousands of years. Indeed, it started a hemispheric transfer, that is the 'Columbian Exchange' of people, plants, animals and minerals, which altered both the 'Old' and 'New' worlds in significant ways (Nunn \& Qian 2010: 163 - 188). From this period onwards, Western European conquest and colonisation activities, which centred on the Atlantic Ocean system, paved the way for the gradual buildup of wealth and power that enabled these societies to establish their dominance over much of the globe by the mid-1700s, creating a situation that still exists today (Tignor et al. 2008: 517 -543).

Greater contact and connections established between different societies did not always have positive outcomes. As mentioned earlier, transregional and/or continental connections led to the spread of many different kinds of things. This also included destructive, unseen microorganisms, such 
as devastating pathogens. In our course, we focus on two diseases that had enormous influences on the making of the modern world: the Black Death in the medieval period and smallpox in the early modern period. Both diseases set the stage for epochal transformations in world history. The first on societies living in the known 'Old World' at the time, Afro-Eurasia, and the second on societies that had been living worlds apart (isolated) for thousands of years, and had been brought into contact for the first time by Spanish conquistadors when they explored and conquered Native American societies in the 'New World'. Certainly, when the time came for various conquistadors to begin their conquests, Jared Diamond has argued that it was germs, not guns that enabled their success, as they found Native American societies already seriously weakened or felled by diseases the Europeans had inadvertently brought with them (Diamond 1998: Chapter 11) .

The above brief description of the course reveals the broad spectrum of themes we examine in HIST 104. It is this course content that we had to reconceptualise and restructure for online teaching when South Africa's lockdown began earlier this year. In our next section, we reflect critically on some of the challenges we have faced as lecturers teaching via online platforms in a resource-constrained South African university environment.

\section{Online Teaching Challenges during COVID-19}

The Covid-19 pandemic took the world by surprise in terms of its rapid spread and high death rates. As mentioned earlier, many governments around the globe implemented various lockdown policies to try to protect their citizens, which led to the temporary shutdown of many non-essential services. The education sector was particularly hard hit. A UNESCOaffiliated organisation, Global Education Coalition, estimated in April 2020 that approximately a billion students across the world had been affected by

${ }^{4}$ The most deadly infectious diseases that negatively affected Native American populations during the first two centuries of contact with Europeans included smallpox, measles, plague and influenza. See for example Lovell 1992: 426-443. Tignor et al. (2008: 532) have argued: 'The scale of death was and remains unprecedented. Imported pathogens wiped out up to 90 percent of the Native American population, which stood at between 80 and 100 million in 1492'. 
school and tertiary education closures due to the Covid-19 outbreak (UNESCO 'Global Education Coalition' 2020). The World Bank Group on Education noted on the 8 April 2020 that universities and other tertiary institutions in 175 countries had closed, and over 220 million post-secondary students had their studies disrupted or ceased as a result of the pandemic (World Bank Group on Education 2020).

To mitigate the disruptions caused by this pandemic, education institutions around the world have sought ways to adapt, and importantly to sustain their academic programmes, amidst lockdown. These institutions, and indeed their lecturers; the people at the frontline of the teaching and learning process, have been confronted with the challenges of having to rethink their academic programmes and teaching approaches, shifting from the traditional face-to-face contact teaching to online (or virtual) teaching modalities. Globally, many tertiary institutions, which have advanced technological infrastructures, such as the United Kingdom, Canada and the United States of America, have taken this path, replacing face-to-face teaching with digital delivery approaches, including live or recorded video or audio lectures and online seminars and tutorials (Cooper 8 April 2020). However, it has also created several teething problems. Amongst the key challenges have been: familiarising lecturers, tutors and students with new online teaching approaches and learning platforms, replacing laboratory work with online technologies and dealing with students' feelings of abandonment caused by the absence of face-to-face contact (Cooper 8 April 2020). In many developing countries, such as in Sri Lanka, Kenya, Sierra Leone and Liberia there have been more acute problems. These include inadequate provision of Information and Communication Technology (ICT) infrastructure for the use of online technologies, lack of exposure to elearning options, and lack of access by students to equipment and data to engage in e-learning (Andersson 2008).

In South Africa, schools and universities were also required to close to prevent the virus's spread amongst their staff and students. This was mandated towards the end of March 2020 when the South African government imposed a 21-day total lockdown (BBC News 27 March 2020). As a result, South Africa faced comparable restrictions on face-to-face contact teaching as many other parts of the world. Recognising that without a cure, social distancing restrictions might continue for many months, many education institutions, but particularly tertiary institutions, sought to shift 


\section{Kalpana Hiralal \& Vanessa Noble}

their teaching to online platforms to try to complete the 2020 academic year. For example, because of the outbreak of the pandemic, the University of Cape Town approved in April a revised academic calendar that incorporated remote teaching throughout its second and third terms, with an anticipated return to contact teaching on campus in the fourth term (IOL 20 April 2020). At the University of the Western Cape (UWC), management devised a 'comprehensive plan' to complete the 2020 academic year with the aid of online teaching. Keenly aware that there are problems with relying only on this approach, and given that students come from varying socio-economic backgrounds, UWC worked on producing a 'contingency plan' to address inequities. This involved a 'catch-up phase' to accommodate students who failed to access online material during the lockdown. This policy allowed these students to complete their work and assessments later in the year. In addition, efforts were made to provide students with data, laptops and flash drives. The rationale for this was a 'flexible learning and teaching approach' to assist students who had no resources or might be 'left behind' (IOL 20 April 2020).

Following President Cyril Ramaphosa's decision to implement the lockdown, UKZN, which currently has over 50,000 students and 9,000 staff spread over five campuses, and until the lockdown, approximately 23,000 students living in its residences, also closed its doors to staff and students, except for a few 'essential service' staff, who were permitted to access its campuses (IOL 20 April 2020). Subsequently, the University established a Teaching and Learning Task team to deliberate and devise a way forward for the implementation of online teaching. The academic staff, as well as students, were asked to fill in online surveys in March and April 2020, respectively. These surveys were designed to determine staff and students' readiness, as well as the problems they faced with accessing and using online modes of delivery to help UKZN formulate a response to support students and staff with this undertaking. The staff survey revealed that many academics required training with regard to online teaching. Furthermore, many staff complained about high data costs, poor connectivity, and the anxieties related to the pandemic ('School of Social Sciences Staff Survey Online Teaching and Learning' March 2020). The student survey revealed the main, deep-seated logistical problems. The key issues were: lack of access to equipment (e.g. smart devices such as laptops or tablets), high data costs, and connectivity problems related to inadequate ICT infrastructure 
where they lived ('School of Social Sciences Student Online Preparedness Survey’ April 2020).

To prepare the teaching staff, in particular those unfamiliar with online platforms, the University's Teaching and Learning Office (UTLO) and Information and Communication Services (ICS) divisions ran several training sessions during April and May 2020. UKZN's academic and professional staff were encouraged to attend these sessions via Zoom, where they were instructed on how to use video communications technology for teaching, but also how to use, digital platforms, such as Moodle and Google Classroom to deliver online content. Training included uploading lecture notes and readings onto these platforms for students, creating and compressing video-recorded PowerPoint lectures, embedding audio into PowerPoint lectures (which was less data-hungry than the video PowerPoint option), setting up a variety of online assessments, and engaging with students using asynchronistic discussion and synchronistic web chat forums.

Although the University has not been able to solve the broader structural connectivity issues faced by students living in some townships and many rural areas, it has worked to mitigate the data and technology challenges. Firstly, the University managed to deliver laptops and data to qualifying students. As of 3 June 2020, $90 \%$ of the first batch of 6000 laptops were delivered (IOL 18 May 2020). Secondly, it entered discussions with South Africa's major telecommunications companies, such as Vodacom, MTN, Cell C, and Telkom Mobile, which led to the roll-out of free - to the user, though not to the University - data bundle packages to both staff and students in May (IOL 18 May 2020). On 3 June, these packages were rolled out to all students except approximately 400, who had been difficult to contact ('Update on the Update on the Rollout of Online Teaching, Communique from the Office of the Vice-Chancellor' UKZN Facebook page 3 June 2020). Thirdly, the University's ICS sector also negotiated with these telecommunication companies a 'zero-rated' status for eleven of UKZN's most used URLs, including Moodle, meaning that the University and not students bore the costs of visiting these sites (IOL 18 May 2020). Fourthly, the home addresses of all registered students were geo-mapped to establish their exact locations within the country to determine how many students were in areas with inadequate Wi-Fi coverage. Linked to this, UKZN also explored the possibility of providing 'Wi-Fi hot-spots' for these students ('UKZN Teaching and Learning Communiqué' email, 1 June 2020, 'UKZN 
Launch of Remote Learning', Email: 30 May 2020). Finally, the university set aside May 2020 as a trial period, or 'Dry Run' session. This period sought to test the readiness of online platforms, such as Moodle and Zoom, and to determine the accessibility and functionality of these teaching platforms. In addition, it sought to encourage students to complete 'mock assessments' loaded on Moodle, to provide insight on the viability of conducting assessments via online platforms. ('UKZN Teaching and Learning Communiqué', Email: 1 June 2020, 'UKZN Launch of Remote Learning', Email: 30 May 2020).

As alluded to earlier, we have been using and teaching with Moodle for many years to assist us with our face-to-face contact teaching for our HIST 104 course. We have used it primarily as a communication tool to make announcements, and to make available readings, tutorial work as well as assignments, such as essays, for our students. The Covid-19 pandemic, however, forced us not only to maximise Moodle's learner-centric tools but also to re-think and redevelop our teaching approaches in the context of delivery and assessments. Thus within a short space of time, we had to move from traditional to completely digital forms of teaching and learning. This presented a myriad of challenges.

As academics, one of the immediate difficulties we faced was learning to convert teaching material that was geared towards face-to-face contact teaching to online teaching for a class of over 700 students. This either required us to transform our lectures into live-streamed lectures via Zoom or recorded video or audio PowerPoints that we could upload on Moodle so that students could watch this material in their own time. Unfamiliar with how to develop these online teaching aids, we enrolled in several digital teaching online seminars and workshops provided by UKZN between April and May. After doing these workshops, we chose to use recorded PowerPoint lectures, as we came to see how Zoom live streaming of lectures would pose too much of a challenge due to students' connectivity issues and its large data consumption. Besides, Zoom accommodates only a limited number of users in one session, which would have meant repeating lectures to cover material for our large class. Overall, the training sessions were enriching as they led to our capacity building in terms of acquiring new skills. However, the pressurised time frame in which we had to learn these new skills, and the practical aspects of creating recorded video or audio PowerPoints for upload on Moodle, was taxing and time-consuming. 
This process also required us to re-think and revise the content of our first-year History course. When teaching for this 14-week course ceased in the fifth week of this academic year, in light of Covid-19, our teaching and learning line managers advised us to reduce the overall number of themes in our course to accommodate what they envisaged would be a slightly shortened first semester of online teaching. Hence, lecture themes per week were to be recorded in several shortened 5-10 minute video PowerPoint lectures or 15-20 minute audio only PowerPoint lectures that did not consume too much data for the students. ${ }^{5}$. This was very different from our usual 45 minutes (single) or 90 minutes (double) lecture periods. We thus had to reexamine our course learning outcomes and themes, and focus on restructuring our shortened lectures to teach only the most fundamental issues to achieve the primary learning outcomes of this module, which was intellectually challenging and stressful in a time-pressured situation. The lecture material was made available at the start of each new week together with instruction emails informing students about the themes for each week and online resources made available for them to go through to prepare for each week's themes.

In addition, the pandemic pushed us to reconsider staff and tutor mentoring and support strategies to help our students learn remotely. Given that our students' learning capacity was diverse, we had to learn to communicate and engage with, as well as to provide guidance and feedback to our students through online platforms such as Moodle. Other than learning how to use online Moodle discussion and webchat forums to mentor and engage our students, we were also required to teach our tutors how to use these online platforms to tutor students online. We provided such instruction through Zoom. From 1 June until 10 July, we created 12 webchat sessions per week, scheduled on different days and at different times, which were 90 minutes each in length. Students were reminded each day, via Moodle announcements, about the web chats times for the following day to encourage participation. These webchats sought to create a live setting to provide students with a means to interact with their tutors each week. On this platform, they could ask questions about the themes covered in the course.

${ }^{5}$ Of course, these shortened video PowerPoint lectures and audio PowerPoint lectures did not stand alone, but were designed to accompany lecture notes, which were provided for students, as well as readings for each lecture theme. 


\section{Kalpana Hiralal \& Vanessa Noble}

As course coordinators and teachers, we too participated in several weekly webchat sessions to interact with the students. Furthermore, we remained available on email in case our students preferred to communicate one-on-one via this medium.

Another area that required re-thinking was our course assessments. This too had to be revised in line with online learning. During the pre-Covid19 period, our planned assessments included three, one-hour, sit down inclass tests for this large class, which covered a broad range of themes in the weeks leading up to each test. The original test structure consisted of a series of map identifications, short answer questions, and paragraph length questions. Marked scripts were then reviewed with tutors in tutorial sessions, to provide feedback to students on their performance. The final exam, if it had gone ahead as planned, would have consisted of a sit-down, three-hour paper covering themes from the 14 weeks of the course, with the same format as the class tests, though with an additional element, a short essay included.

Of course, the outbreak of the pandemic necessitated alternative approaches to assess and provide feedback for our students. After completing online training on how to develop online assessments, we created three online quizzes on Moodle to assess the course content. These quizzes were made up of MCQ, true/false, chronology, definitions, and mix and match questions. We chose the online quiz format as although it took longer to create, it enabled quicker marking, which was essential for us to assess a large class in a limited amount of time. Pedagogically, these quizzes were designed to push students to think analytically when they had to choose the correct answer from amongst multiple choices. They were also designed to encourage them to think conceptually, when they had to define important concepts, and chronologically, when they had to choose the correct dates or time periods of historical events in a selection of choices. We also set the quiz questions in shuffle mode, to limit the ability of students to copy from one another. The tests were set so that students could only make one attempt at the quiz.

Furthermore, we designed these quizzes as 'open book' tests so that students could use their notes and readings to answer the questions. These quizzes were made available to students immediately after we completed the content of our online teaching, and remained open for students to complete for a month, that is, until the last day of the semester. We did this to try to accommodate the many students who experienced Wi-Fi access problems or 
power outages and gave them time to submit these assessments in their own time. Finally, constructive feedback was built into each quiz, so once Moodle closed the quizzes on the final submission date, students could see their marks, as well as the feedback related to all of their answers.

One of the big themes that we focused on in our course was the impact of diseases on world history. Although we had limited time this semester to provide an in-depth study of diseases, such as the Black Death and smallpox and their role in the making of the modern world, just as Covid19 has pushed us to reflect on parallels between this pandemic and historical pandemics, we are thinking, in future years, of encouraging our students to also reflect, in a more substantive manner, on their experiences of having lived through Covid-19 in comparison to a past pandemic. We envisage that this could take the form of a formative or summative assessment that would ask them to read about a past pandemic and then get them to do some research and draw parallels with Covid-19 based on their own experiences and drawing on online media material on Covid-19. This would provide a meaningful way to show students the value of studying the past, particularly how the past can provide deeper understandings, but also lessons for the present handling of pandemics.

Despite all the training we have done as well as the effort we have put into re-thinking and revising our HIST 104 course to make our teaching material available online for our students, in South Africa, there were still many challenges. One of the biggest challenges we faced at higher education institutions this past semester was the lack of financial means amongst our students and inequitable ICT infrastructures in the country. These issues, according to some critics and academics have had enormous implications for the rollout of quality online teaching. According to Pedro Mzileni, a Ph.D. Sociology candidate at Nelson Mandela University:

South African universities were conceptualised as residential institutions which utilise traditional teaching and learning contact. Even with the technological advancements and innovations that our universities have scored thus far, they still require their undergraduate cohort of students to be physically hosted in the campus residential precinct to utilise them. Put differently; no technological shortcut has managed to sweep our country's socioeconomic inequalities under the carpet (Mzileni 23 April 2020). 


\section{Kalpana Hiralal \& Vanessa Noble}

Despite UKZN's efforts to reduce students' data and technical difficulties, many of these challenges came to the fore during the 'Dry Run' period. To test our students' preparedness to study online for our History 104 course, during this period, we developed a mock video/audio recorded PowerPoint presentation that explained how online learning was to proceed for our course, as well as a mock online quiz. However, about half of our 722 registered students were not able to access this material ${ }^{6}$. In email communications from students, and through information obtained from additional online surveys conducted by UKZN during its 'Dry Run' period, but also during the main online teaching period from 1 June to $10 \mathrm{July}$, it became evident that many problems faced our students. ('Report on Staff Survey to Evaluate the Effectiveness of Online Teaching and Learning DRYRUN at UKZN', June 2020).

Many of our students come from rural areas, villages, and townships, which do not have the necessary ICT infrastructure, making sustained and fast internet connectivity possible. When they returned home during the lockdown period, this lack of infrastructure made their internet connectivity poor or non-existent, which made it more difficult for these students to access the lecture notes and readings, never mind the larger recorded video and audio PowerPoint lecture files to study via online means. As two students highlighted in communications with us:

Student A: Good morning ... I'm registered for History 104 module, I saw yesterday an email and I'm having difficulty in accessing Moodle. I'm really scared that I'm being left behind, I have never assessed Moodle before because of network problems at home (Email communication, 30 June 2020) ${ }^{7}$.

Student B: I want to tell you that I haven't been studying, because I' $m$ in a rural area, where there is no network, we travel a long distance to get it, and it is not safe for us as gals, the not[es are not]

6 We could see this from the number of students who attempted and completed the quiz, which is recorded on our Moodle course website.

${ }^{7}$ To protect the identities of the students whose comments we used in this article, we have opted not to use their names. We received permission from each student to use his/her email comments. 
downloading, the work is a lot. I am behind (Email communication, 30 June 2020).

One of the key challenges for our students was a lack of data. Several of the University's plans to roll out data, Wi-Fi hotspots, and laptops encountered delays due to supply problems, delivery restrictions during the lockdown, and inability to contact some students whose details were not up-to-date on the University system. This further hindered students' online learning. Some students did not have laptops or tablets, only cell phones to access their learning material, which made it difficult to download and study. Whilst the University has made enormous strides to assist UKZN students in accessing their learning materials online, these factors highlight many disparities that face students in terms of studying online ('Report on Staff Survey to Evaluate the Effectiveness of Online Teaching and Learning DRY-RUN at UKZN, June 2020'; 'Update on the Rollout of Online Teaching, Communique from the Office of the Vice-Chancellor', UKZN Facebook page, 3 June 2020; IOL, 18 May 2020).

We also have students who come to UKZN from disadvantaged home backgrounds that are not conducive to studying. Indeed, when the UKZN residences closed in March, many students were forced to return to living in large, congested households where space was limited, it was noisy, and they had to contribute to domestic chores and child care responsibilities, which diverted their attention away from their studies. As the following students wrote, capturing well these problems:

Student C: ... some of us don't have data for Moodle or we are too busy doing things around the house that we don't even get time to go on Moodle [to study] (Email communication, 9 June 2020).

Student D: I'm from rural area I couldn't get to my Moodle due to the poor connection, totally there is no network and I heard that there are many notes that are uploaded on Moodle but I'm stressed how to finish it. I live in single room with 8 siblings and my parents. I can't focus on my school work. May you please help me on what can I do to return on res. so that I can cover this work? (Email communication, 29 June 2020). 
Because of these difficult home environments, several students wrote to us pleading that they be allowed to return to campus. A student who was living in an overcrowded four-roomed house in Clermont KwaDabeka made a good example of this type of request:

Student E: I write this email seeking your help due to the problems I'm facing with the online learning program ever since this pandemic started .... At home we are crowded, there's not enough space for me to study and I don't get much time to study ... because of the house chores I do most of the times. The place I live in is very noisy even at night I cannot concentrate due to the noise. Please consider me as an essential student to return back to resident or campus because of the fear I have that I might not be able to pass my modules and be academically excluded (Email communication, 2 July 2020).

Anxiety about learning via online platforms was also evident in emails from some students who contacted us. Concerns were related to finding and listening to lectures online. Others were associated with unease around using the unfamiliar live or synchronistic web chat platform in Moodle to ask questions and discuss course content. Log in problems were also common. As one student (Student F) noted: 'Good day Professor. I tried to enter the web chat session with you earlier and I was receiving a message saying that my UKZN [account] .... is not responding but I could view the history of it'. (Email communication, 2 July 2020).

Our online open-book quizzes, which few, if any students had encountered before, generated a lot of anxiety too for many of our students. Although we took the time, well before the quizzes were due, to send numerous announcements explaining the form, content, and timing of these quizzes, these issues were still some of the biggest assessment-related concerns, as several students' emails demonstrate:

Student G: I want clarity about [the] quizzes. [Will] they [be] like assessment or test[?] [Will] students... have enough time to answering them as deadline of submission is on 11 August 2020 or [yo]u have 30 minutes per quiz to attempt it? (Email communication, 7 July 2020). 
Student H: Morning mam, I would like to ask ...if the quiz have a limited time or you can do the quiz for hours? (Email communication, 14 July 2020).

Other assessment worries related to students' network or data problems, which produced difficulties or delays in accessing the quizzes:

Student I: Please can you make it [the quiz submission date] after this week because some of us are still struggling about the data and they said it will be brought to us by Monday (Email communication, 11 June 2020).

During the pandemic, teaching and learning were stressful for both lecturers and students. Analysis of the last student's email, in particular, reveals high levels of anxiety. Poor connectivity, lack of data, and overcrowded home learning environments exacerbated students' apprehensions. Many students were 'really scared' about being 'left behind'. For many students accessing online learning and assessment platforms from home during the last few months of the Covid-19 pandemic was a 'new phenomenon'. This is indicative of how dependent our students are on university facilities and the deep levels of poverty that still exist amongst the vast majority of South Africans.

Working with University structures, we as academics and course coordinators tried to assist our students in various ways to make online learning as conducive as possible. As mentioned earlier, online quizzes were specifically designed as open-book assessments, which remained available to students over several weeks, to enable as many students as possible to complete these assessments in challenging remote access circumstances. In addition, in line with UKZN policies, during the University's 'Catch-Up' period, we designed and uploaded three more open-book quiz assessments to enable students who had failed their main course assessments a second chance to pass our course ('Communique from the Office of the Deputy Vice-Chancellor: Teaching and Learning - Catch-Up Plan', 7 July 2020). Moreover, we forwarded queries regarding poor connectivity, data, and hardware (computer) issues immediately to our Information and Communication Services (ICS) department, with our Cluster Leaders and Academic Leader for Teaching and Learning cc-ed into all email corres- 


\section{Kalpana Hiralal \& Vanessa Noble}

pondence to enable follow up.

In these very challenging circumstances, we also sought to assist very anxious students by putting them in touch with UKZN's Student Support Services (SSS), where trained psychologists provided online and/or telephonic counseling for such students. During the remote teaching period, SSS also ran a structured weekly programme that provided assistance in the following areas: 'First Year Support Group', 'Dealing with the impact of COVID-19 Support Group', 'Students who are Mothers Support Group', 'Women Empowerment Support Group' and 'Anxiety Support Group'. (Flyer: College of Humanities Student Support Services: Angeline Stephens: Email to K. Hiralal, 7 September 2020).

\section{Conclusion}

Covid-19 has pushed us to ask questions about our roles as academics in a time of crisis. How do we re-think our traditional roles from visible to invisible teachers, in other words, from face-to-face teaching to online learning? Drawing on our own experiences as university lecturers, we have alluded in this article to the challenges we have experienced thus far using online technologies to develop and deliver our lectures to our large first-year class of History students. To date, on our online teaching journey, meeting the challenge of Covid-19 has been challenging and stressful, but also intellectually stimulating. As lecturers, we have been pushed out of our comfort zones, forced to reconceptualise our course material, and reimagine what we have done in terms of our teaching pedagogy for years. This disease outbreak has also encouraged us to learn new things by undergoing training to produce and deliver our lecture content online. The pandemic has revealed new possibilities in higher education in terms of curriculum development and modes of teaching for the twenty-first century.

However, when it comes to online learning, many challenges still remain for our students due to problems accessing technology and digital resources. Certainly, we are living in a globally connected world, but one that is not equally connected for all. In the last few months, much has been done by our University, and ourselves to encourage teaching and learning and to accommodate as many students as possible in the difficult circumstances of the Covid-19 lockdown. Though, much still needs to be done to improve our students' remote learning experience. Experience has 
been an excellent teacher. Looking ahead, we will take what lessons we have learned from this semester and apply it to our future online teaching. Currently, we do not know the severity or the long-term impact of Covid-19, but it will likely be a rocky road for ourselves and our students as we navigate this new online teaching and learning terrain together.

\section{References}

Abu-Lughod, J.L. 1989. The World before European Hegemony: The World System A.D. 1250 - 1350. New York and Oxford: Oxford University Press.

Andersson, A. 2008. Seven Major Challenges for E-Learning in Developing Countries: Case Study eBIT, Sri Lanka. IJEDICT 4: 3. Available at: http://oru.diva-portal.org/smash/get/diva2:201280/FULLTEXT01.pdf (Accessed on 1 June 2020.)

Cooper, F. 2001. What is the Concept of Globalization Good For? An African Historian's Perspective. African Affairs 100: 189 - 213.

Cooper, V., 8 April 2020. COVID-19: Higher Education and Student Related Challenges. Bevan Brittan. Available at:

http://www.bevanbrittan.com/insights/articles/2020/covid-19-highereducation-and-student-related-challenges/ (Accessed 1 June 2020.)

Coronavirus: South Africa Reports First Deaths as Lockdown Begins. BBC News 27 March 2020. https://www.bbc.com/news/world-africa52058717 (Accessed on 30 May 2020.)

Coronavirus Cases. Worldometer.

https://www.worldometers.info/coronavirus/coronavirus-death-toll/ (Accessed on 7 September 2020)

Diamond, J. 1998. Guns, Germs and Steel: A Short History of Everybody for the Last 13,000 Years. London: Vintage.

Global Education Coalition.

https://en.unesco.org/covid19/educationresponse/globalcoalition (Accessed on 2 June 2020.)

IOL, 20 April 2020. This is How SA Varsities are Implementing Online Teaching amid Covid-19 Lockdown. Available at: 
https://www.iol.co.za/capeargus/news/this-is-how-sa-varsities-areimplementing-online-teaching-amid-covid-19-lockdown-46930129 (Accessed on 1 June 2020.)

IOL, 18 May 2020. UKZN Rolls out Free Data Bundles and Laptops to Students for Online Teaching during COVID-19. Available at:

https://www.iol.co.za/dailynews/news/kwazulu-natal/ukzn-rolls-outfree-data-bundles-and-laptops-to-students-for-online-teaching-duringcovid-19-48089453 (Accessed on 1 June 2020.)

Lovell, W.G. 1992. 'Heavy Shadows and Black Night': Disease and Depopulation in Colonial Spanish America. Annals of the Association of American Geographers 82, 3: 426 - 443.

Moore, R.I. 1997. World History. Companion to Historiography. Bentley, M. (ed.). London and New York: Routledge.

Mzileni, P. 2020. How Covid-19 will Affect Students. The Mail and Guardian 23 April 2020. https://mg.co.za/education/2020-04-23-howcovid-19-will-affect-students/ (Accessed on 15 May 2020.)

Nunn, N. \& N. Qian 2010. The Columbian Exchange: A History of Disease, Food and Ideas. Journal of Economic Perspectives 24, 2: 163 - 188.

Poku, N. 3 June 2020. Communiqué from the Office of the Vice Chancellor, Update on the Rollout of Online Teaching. 3 June 2020, UKZN Facebook page, https://web.facebook.com/notes/university-of-kwazulu-natal/update-onthe-rollout-of-online-teaching/3525200080841445/?_rdc=1\&_rdr (Accessed 30 August 2020.)

Ponting, C. 2001. World History: A New Perspective. London: Pimlico, School of Social Sciences, March 2020. School of Social Sciences Staff Survey - Online Teaching and Learning, compiled by the UKZN School of Social Sciences Online Learning Task Team.

School of Social Sciences, April 2020. School of Social Sciences Student Online Preparedness Survey. Compiled by the UKZN School of Social Sciences Online Learning Task Team, April 2020.

Stephens, A. 2020. Flyer: College of Humanities Student Support Services:

Email to K. Hiralal 7 September 2020.

The World Bank Education, 9 April 2020. The COVID 19 Crisis Response: Supporting Tertiary Education for Continuity, Adaptation and Innovation. Available at: 
http://pubdocs.worldbank.org/en/621991586463915490/WB-TertiaryEd-and-Covid-19-Crisis-for-public-use-April-9.pdf (Accessed on 9 June 2020.)

Tignor, R., J. Adelman \& E. Pollard 2008. Worlds Together, Worlds Apart:

A History of the World. Volume Two: The Mongol Empire to the Present. Second Edition. New York and London: W.W. Norton \& Company.

UKZN Email: UKZN Teaching and Learning Communiqué: 1 June 2020, Launch of Remote Learning, 30 May 2020.

UKZN Email: UKZN Rolls out Free Data Bundles and Laptops to Students for Online Teaching during Covid-19, 3 June 2020.

UKZN, Report on Staff Survey to Evaluate the Effectives of Online Teaching and Learning DRY-RUN at UKZN, June 2020.

https://www.news24.com/SouthAfrica/News/dettol-garlic-and-fake-

cases-in-north-west-cape-debunking-the-hoaxes-lies-around-

coronavirus-20200306 (Accessed on 25 June 2020.)

UKZN 2020. Communiqué from the Office of the Deputy Vice-Chancellor: Teaching and Learning - Catch-Up Plan. Email: 7 July 2020.

Professor Kalpana Hiralal Historical Studies University of KwaZulu-Natal Hiralalk@ukzn.ac.za

Dr. Vanessa Noble Historical Studies University of KwaZulu-Natal Noblev1@ukzn.ac.za 